\title{
АНАЛИЗ ФИНАНСОВЫХ РЕЗУЛЬТАТОВ ПО СЕЛЬХОЗПРЕДПРИЯТИЯМ АКМОЛИНСКОЙ ОБЛАСТИ РЕСПУБЛИКИ КАЗАХСТАН
}

\author{
Саутбекова О.К \\ г. Астана, Республика Казахстан
}

\section{РЕЗЮМЕ}

Скотоводство является превалирующей отраслью животноводства. Это обусловлено тем, что крупный рогатый скот дает более 99 \% молока и около 50 \% говядины - главных животноводческих продуктов питания населения нашей планеты. Увеличение производства высококачественных продуктов скотоводства проблема с годами, не теряющая своей актуальности, а все больше приобретающая значение как с ростом населения нашей планеты, в частности нашей страны, так и удовлетворения потребности этой отрасли придается большое народнохозяйственное значение.

КЛЮЧЕВЫЕ СЛОВА: Валовая продукция, себестоимость, рентабельность, продуктивность

\section{ВВЕДЕНИЕ}

В послании Президента Республики Казахстан «Построим будущее вместе!» особое внимание обращается на реализацию беспрецедентного проекта по развитию мясного животноводства. Это важно, т.к. на современном этапе большое значение приобретают вопросы роста переработки сельскохозяйственного сырья, реализации экспортного потенциала, увеличения поголовья племенного и породного скота.

\section{МАТЕРИАЛЫ ИССЛЕДОВАНИЯ, МЕТОДОЛОГИЯ}

Теоретической и методологической основой исследований выступили труды известных отечественных и зарубежных ученых-экономистов, посвященные проблемам развития отрасли скотоводства. В процессе работы изучены и проанализированы основные нормативные и законодательные акты Республики Казахстан, концепции и программы реформирования АПК страны. В качестве информационной базы исследования использованы материалы статистической отчетности Агентства Республики Казахстан по статистике, Управлений статистики Акмолинской области, материалы сети INTERNET.

B зависимости от цели и задач в работе используются различные методы исследования: экономико- математический - для исследования оптимизации использования ресурсов при производстве продукции; статистико-экономический - для проведения корреляционно-регрессионного анализа; монографический - при обследовании отдельных сельскохозяйственных формирований. При проведении расчетов используется программный продукт MS Excel.

\section{РЕЗУЛЬТАТЫ ИССЛЕДОВАНИЯ}

За 2008-2010 годы валовая продукция животноводства в общем объеме валовой продукции сельского хозяйства области составила от 32,8 до 47,9\%. По итогам 2010 года объем валовой продукции животноводства области составил 52,1 млрд. тенге. По сравнению с 2008 годом валовая продукция увеличилась на 15,2\%, однако, по сравнению с 2009 годом за счет хозяйств населения произошло уменьшение на 0,6\%. В хозяйствах населения объем валовой продукции животноводства снизился на 3,3\% в связи с уменьшением производства основных видов продукции животноводства. По сельхозпредприятиям валовая продукция увеличилась на 21,2\%, по крестьянским (фермерским) хозяйствам - 14,9\%, однако, их доля в общем объеме валовой продукции незначительна (12,6\% и 1,2\%, соответственно). 
Таблица 1

Валовая продукция сельского хозяйства (млрд. тенге)

\begin{tabular}{|c|c|c|c|c|c|c|c|c|}
\hline & \multicolumn{4}{|c|}{ Валовая продукция - всего } & \multicolumn{3}{|c|}{ в том числе животноводство } & \multirow[b]{2}{*}{$\begin{array}{c}2010 \text { гК } \\
2009 \text { Г } \\
\text { в \% }\end{array}$} \\
\hline & $2008 \Gamma$ & $2009 \Gamma$ & $2010 \Gamma$ & $\begin{array}{c}2010 \text { гк } \\
2009 \Gamma \\
\text { в \% }\end{array}$ & $2008 \Gamma$ & $2009 \Gamma$ & $2010 \Gamma$ & \\
\hline Bce категории & & & & & & & & \\
\hline $\begin{array}{l}\text { хозяйств } \\
\text { в том числе: }\end{array}$ & 138,0 & 201,9 & 108,9 & 53,9 & 45,2 & 52,5 & 52,1 & 99,4 \\
\hline $\begin{array}{l}\text { Сельхозпредприят } \\
\text { ия }\end{array}$ & 70,6 & 111,7 & 41,6 & 37,3 & 3,9 & 5,4 & 6,5 & 121,2 \\
\hline $\begin{array}{l}\text { крестьянские } \\
\text { (фермерские) } \\
\text { хозяйства }\end{array}$ & 18,1 & 26,1 & 9,2 & 35,3 & 0,5 & 0,5 & 0,6 & 114,9 \\
\hline $\begin{array}{l}\text { хозяйства } \\
\text { населения }\end{array}$ & 49,2 & 64,1 & 58,1 & 90,6 & 40,8 & 46,5 & 45,0 & 96,7 \\
\hline
\end{tabular}

В течение последних трех лет удельный вес валовой продукции животноводства Акмолинской области в общереспубликанском объеме составлял от 7,3 до 6,7 $\%$.

Разведением скота и птицы занимаются во всех районах области. Наибольшее поголовье крупного рогатого скота содержится в Зерендинском (10,6\% от всего поголовья области), Ерейментауском (9,0\%), Целиноградском $(8,4 \%)$, Бурабайском $(8,3 \%)$, Астраханском (8,2\%) районах; овец и коз - в Ерейментауском $(17,6 \%)$, Зерендинском $(11,8 \%)$,
Енбекшильдерском (6,9\%), Атбасарском (6,7\%), Целиноградском и Бурабайском $(6,6 \%)$ районах; свиней - в Астраханском (13,3\%), Шортандинском $(12,2 \%)$, Есильском (10,7\%), Атбасарском (8,9\%) районах; лошадей - в Зерендинском $(11,4 \%)$, Ерейментауском $(11,3 \%)$, Атбасарском $(8,5 \%)$, Целиноградском $(8,4 \%)$, Бурабайском $(8,0 \%)$ районах; птицы - в Енбекшильдерском (23,2\%), Аршалынском $(21,6 \%)$, Целиноградском (16,8\%) и Бурабайском $(13,6 \%)$ районах.

Таблица 2

Поголовье скота и птицы (тыс. голов)

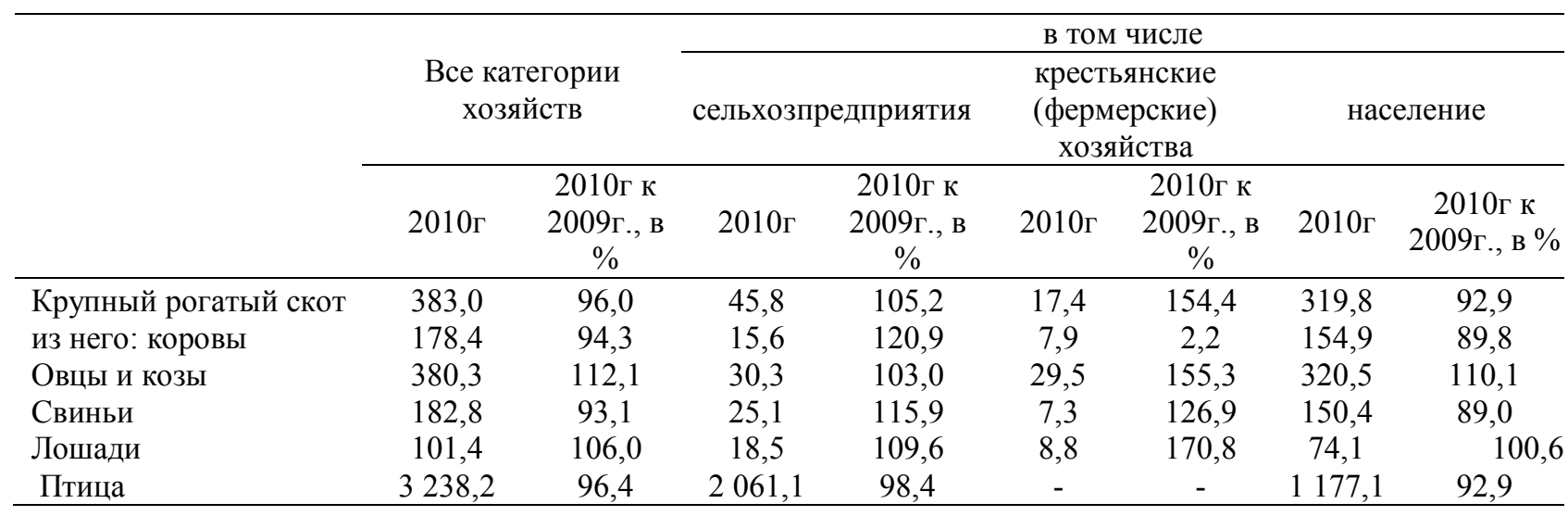

В 2010 году в целом по области по сравнению с предыдущим годом произошел рост поголовья овец и ко3, на $12,1 \%$, лошадей - на 6,0\%. Поголовье овец и коз увеличилось в Ерейментауском (на 42,1\%), Аршалынском (35,8\%), Енбекшильдерском (20,3\%), Жаркаинском (18,1\%), Аккольском $(12,1 \%)$, Атбасарском (11,0\%), Коргалжынском (10,5\%), Есильском (на 7,3\%) районах. Наибольшее увеличение поголовья лошадей произошло в Енбекшильдерском (на 24,1\%), Шортандинском $(18,7 \%)$, Ерейментауском (17,4\%), Аршалынском (16,9\%), Бурабайском (10,1\%), Есильском (на 8,6\%) районах.
Поголовье крупного рогатого скота по области уменьшилось на 4,0\%, из них за счет хозяйств населения на 7,1\%. Наибольшее уменьшение произошло в Жаксынском (на 38,1\%), Атбасарском (16,9\%), Есильском (16,5\%), Аршалынском (13,2 \%), Сандыктауском (на 10,8\%) районах. Наибольшее увеличение поголовья крупного рогатого скота наблюдается в Коргалжынском (на 15,4\%), Бурабайском (13,4\%), Егиндыкольском (на 8,6\%) районах.

Поголовье свиней уменьшилось на $6,9 \%$, из них за счет домашних хозяйств на $11,0 \%$. Поголовье птицы уменьшилось на $3,6 \%$, из них за счет домашних 
хозяйств на 7,1\% и за счет сельхозпредприятий на 1,6\%. Наибольшее уменьшение произошло в Жаксынском районе (на 68,9\%), Бурабайском $(9,8 \%)$, Есильском (на 8,3\%) районах.

По сельхозпредприятиям и крестьянским (фермерским) хозяйствам наблюдается увеличение поголовья всех видов скота. В сельхозпредприятиях увеличилось поголовье крупного рогатого скота (на $5,2 \%)$, овец и коз $(3,0 \%)$, лошадей $(9,6 \%)$, свиней (на $15,9 \%$ ). В крестьянских (фермерских) хозяйствах увеличилось поголовье крупного рогатого скота (на $54,4 \%)$, овец и коз $(55,3 \%)$, лошадей $(70,8 \%)$, свиней (на 26,9\%).
На долю хозяйств населения приходится 83,5\% поголовья крупного рогатого скота, 84,3\% овец и коз, $73,1 \%$ лошадей и $82,3 \%$ свиней. Доля крестьянских (фермерских) хозяйств, несмотря на ежегодный рост, незначительна и составила в 2010 году по крупному рогатому скоту - 4,5\%, по овцам и козам - 7,8\%, лошадям - 8,7\%, свиньям - 4,0\%. Доля сельхозпредприятий во всех категориях хозяйств по поголовью крупного рогатого скота за этот же период составляет $12,0 \%$, по овцам и козам $-7,9 \%$, лошадям $-18,2 \%$, свиньям $-13,7 \%$.

Важными факторами, влияющими на производство продукции животноводства, являются продуктивность и обеспеченность кормами.

Таблица 3

Продуктивность скота и птицы во всех категориях хозяйств Акмолинской области

\begin{tabular}{lccc}
\hline & 2008 г. & 2009 г. & 2010 г. \\
\hline Среднегодовой удой молока на 1 корову, кг & 2637 & 2572 & 2563 \\
Средняя яйценоскость кур - несушек, штук & 179 & 205 & 212 \\
Средний годовой настриг шерсти с одной овцы, кг & 2,5 & 2,5 & 2,5 \\
Средний живой вес скота и птицы, реализованного для убоя на мясо, кг & & 288 & 287 \\
крупного рогатого скота & 285 & 288 & 89 \\
свиней & 91 & 90 & 37 \\
овец и коз & 37 & 37 & 294 \\
лошадей & 305 & 306 & \\
Выход приплода на 100 маток, голов & & & 86 \\
телят & 95 & 93 & 86 \\
ягнят и козлят & 100 & 96 & 861 \\
поросят & 878 & 917 & 861 \\
жеребят & 85 & 84 & 74 \\
\hline
\end{tabular}

За 2008-2010 годы наблюдается увеличение выхода яиц на 1 курицу - несушку (от 179 до 212 штук). Настриг шерсти с 1 овцы в течение трех лет не изменился и составил 2,5 кг. Надой молока на 1 корову снизился с 2637 до 2563 кг. Средняя яйценоскость в 2010 году во всех категориях хозяйств по сравнению с 2009 годом увеличилась на $3,4 \%$. Надой молока на 1 корову уменьшился на $0,3 \%$.

Выход приплода на 100 маток по сравнению с 2009 годом уменьшился по телятам на 7,5\%, ягнятам и козлятам - 10,4\%, поросятам - 6,1\%, жеребятам - на $11,9 \%$.
Средний живой вес одной головы, реализованной на мясо, уменьшился по крупному рогатому скоту на $0,3 \%$, свиньям - $1,1 \%$, лошадям - на $3,9 \%$, овцам и козам остался на уровне 2009 года. На уменьшение продуктивности повлияло снижение количества заготовленных кормов. На 1 декабря 2010 года в сельхозпредприятиях области было заготовлено 83282,6 тонн кормов в пересчете на кормовые единицы, уменьшение к соответствующему периоду прошлого года составило $37,4 \%$. Основную долю в структуре кормов занимают сено, солома, зернофураж.

Таблица 4

Наличие кормов в сельскохозяйственных предприятиях на 1 декабря (тонн)

\begin{tabular}{lcccc}
\hline & 2008 г & 2009 г & 2010 г & $\begin{array}{c}2010 \Gamma . \text { к } \\
\text { 2009Г., в \% }\end{array}$ \\
\hline Концентрированные корма & 50316,5 & 68890,8 & 38606,2 & 56,0 \\
Силос & 16565,4 & 31156,6 & 21051,6 & 67,6 \\
Сено & 62930,8 & 93379,4 & 70287,3 & 75,3 \\
Сенаж & 10613,9 & 18385,4 & 12444,3 & 67,7 \\
Солома яровая и озимая & 44358,0 & 49661,8 & 34405,9 & 69,3 \\
$\begin{array}{l}\text { Все корма в пересчете на кормовые } \\
\text { единицы }\end{array}$ & 94322,2 & 133074,4 & 83282,6 & 62,6 \\
$\begin{array}{l}\text { В среднем на 1 голову в переводе на } \\
\text { условный крупный скот, ц. кормовых }\end{array}$ & & & & 59,3 \\
единиц & 11,6 & 13,5 & 8,0 & \\
\hline
\end{tabular}


В истекшем году низкая обеспеченность кормами на 1 условную голову крупного рогатого скота сложилась в сельхозпредприятиях Шортандинского - 4,1 центнера кормовых единиц, Енбекшильдерского - 4,4 центнера, Есильского - 5,0 центнеров кормовых единиц районов.

Основными составляющими продукции животноводства являются производство мяса скота и птицы, молока, яиц, шерсти.

Таблица 5

Производство основных видов животноводческой продукции

\begin{tabular}{|c|c|c|c|c|}
\hline & $2008 \Gamma$ & 2009 Г & 2010 г & $\begin{array}{c}2010 \text { г. к } \\
2009 \text { г., в \% }\end{array}$ \\
\hline $\begin{array}{l}\text { Скот и птица, на убой } \\
\text { (в живой массе), тыс. тонн } \\
\text { в том числе: }\end{array}$ & 101,6 & 101,1 & 96,5 & 95,5 \\
\hline говядина & 59,7 & 59,7 & 55,8 & 93,5 \\
\hline свинина & 21,7 & 21,1 & 20,5 & 96,8 \\
\hline баранина и козлятина & 7,0 & 6,7 & 6,6 & 99,2 \\
\hline конина & 10,4 & 10,6 & 10,3 & 96,6 \\
\hline мясо птицы & 2,8 & 2,9 & 3,3 & 114,2 \\
\hline Молоко, тыс. тонн & 452,6 & 452,9 & 453,6 & 100,2 \\
\hline Яйцо, млн. штук & 225,4 & 342,0 & 448,0 & 131,0 \\
\hline Шерсть (в физическом весе), тонн & 643,2 & 663,4 & 673,0 & 101,4 \\
\hline
\end{tabular}

За 2008 - 2010 годы наблюдается снижение производства мяса, так в 2010 году по сравнению с 2008 годом уменьшение составило 4,9\%, по сравнению с 2009 годом $-4,5 \%$.

За 2008 - 2010 годы наблюдается увеличение производства молока, на $0,2 \%$.

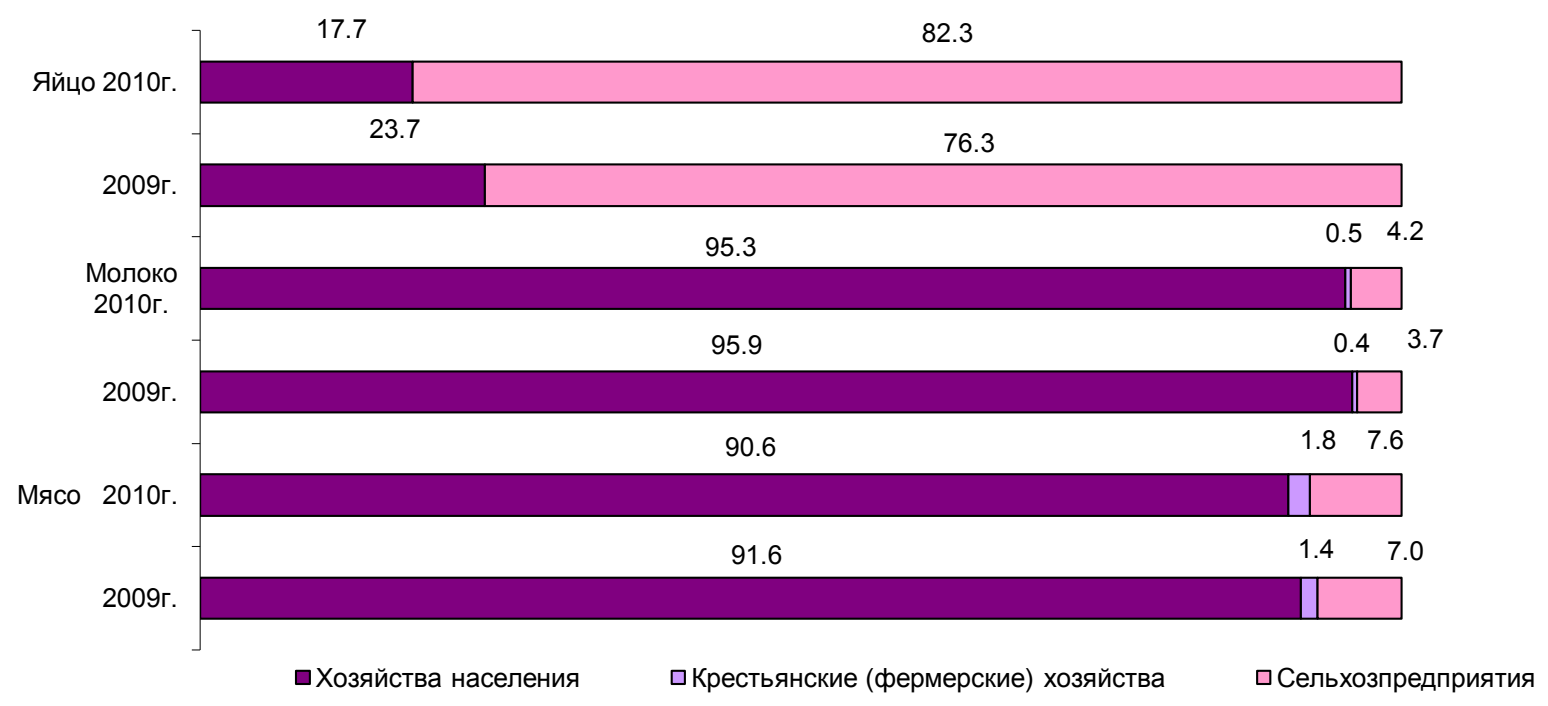

Рисунок 1. Удельный вес категорий хозяйств в производстве основных видов животноводческой продукции

Из вышеприведенных данных видно, что доля сельхозпредприятий по производству мяса и молока не превышает 8,0\%.

Доля крестьянских (фермерских) хозяйств в производстве основных видов животноводческой продукции незначительна и составляет не более 2,0 $\%$.
Производство яиц по сравнению с 2008 годом увеличилось на 98,7\%, по сравнению с 2009 годом $31,0 \%$. Производство шерсти увеличилось на 4,6\% и $1,4 \%$ соответственно.

в процентах 
яиц, что обусловлено промышленным производством яиц.

Производство мяса является одним из важных видов продукции животноводства. Основными производителями мяса являются Целиноградский 10,2 тонны $(10,6 \%$ от областного объема $)$, Зерендинский - 8,9 тонн (9,2\%), Ерейментауский - 7,6 тонн $(7,8 \%)$, Жаксынский - 6,7 тонн $(7,0 \%)$, Атбасарский - 6,5 тонн (6,7\%) районы.

В 2010 году производство мяса в живом весе составило 96,5 тыс. тонн, что на 4,5\% меньше уровня 2009 года. Данные показатели сложились из - за уменьшения производства по домашним хозяйствам, на $5,6 \%$. По сельхозпредприятиям производство увеличилось на 4,2\%, по крестьянским (фермерским) хозяйствам - на 22,0\%. Наибольшее увеличение производства мяса по сельхозпредприятиям произошло в Ерейментауском (в 6,9 раз), Коргалжынском (в 3,7 раз), Зерендинском (в 2,2 раз), Егиндыкольском и Целиноградском (в 1,7 раз) районах.

Производство мяса в убойном весе в 2010 году составило 51567,2 тонны. По сравнению с предыдущим годом наблюдается увеличение мяса птицы на 10,7\%, уменьшилось производство конины на $4,5 \%$, говядины - 4,0\%, свинины - 3,6\%, баранины на $1,0 \%$.

Для увеличения производства мяса необходимо увеличение поголовья скота, повышение продуктивности скота мясного направления, откорм скота в оптимальные сроки до максимальных весовых кондиций, производство мяса с минимальными затратами трудовых и энергетических ресурсов, удешевление себестоимости производимой продукции.
Производство молока в 2010 году составило 453,6 тыс. тонн, или 100,2\% к 2009 году. Увеличение произошло в сельхозпредприятиях на 13,7\%, крестьянских (фермерских) хозяйствах - 10,1\%. По домашним хозяйствам производство молока уменьшилось на 0,4\%. Основными производителями молока - являются Зерендинский $(10,6 \%$ от общего объема производства по области), Целиноградский $(9,9 \%)$, Бурабайский $(8,9 \%)$ Ерейментауский $(7,1 \%)$, Буландынскоий и Атбасарский $(6,9 \%)$ районы.

В 2010 году в области произведено 448,0 млн. штук яиц, рост по сравнению с предыдущим годом составил в 1,3 раза. Увеличение произошло за счет птицефабрик области, в 1,4 раза. В Енбекшильдерском районе производство яиц увеличилось в 2,2 раза, Бурабайском - на 23,6\%, Аршалынском - 22,1\% районах. Этому способствовал ввод в действие птицефабрики «Казгер Кус» в Енбекшильдерском районе, которая в 2010 году вышла на проектную мощность 150 млн. штук яиц в год, проведенной реконструкции и модернизации действующих производств. Также увеличилась поголовье кур - несушек на 35,6 \% и увеличился выход яиц на 1 курицу- несушку на 4,0\%. Производство яиц в хозяйствах населения уменьшилось - на 2,2\%.

Анализ финансовых результатов по сельхозпредприятиям истекшего года показал, что производство яиц, молока, шерсти и мяса является прибыльным, уровень рентабельности составил соответственно, $21,6 \%, 18,8 \%, 11,8 \%$ и 2,6\%. В целом по отрасли уровень рентабельности продукции животноводства составил $14,4 \%$.

Таблица 6

Реализация животноводческой продукции в сельхозпредприятиях Акмолинской области за 2010 год

\begin{tabular}{|c|c|c|c|c|c|}
\hline & $\begin{array}{c}\text { Продукция } \\
\text { животноводства }\end{array}$ & Молоко & Яйцо & Шерсть & $\begin{array}{c}\text { Скот и птица в } \\
\text { живой массе }\end{array}$ \\
\hline $\begin{array}{l}\text { Количество реализованной } \\
\text { продукции, ц., тыс. штук }\end{array}$ & $\mathrm{X}$ & 168577 & 363963 & 588 & 80653 \\
\hline $\begin{array}{l}\text { Себестоимость реализованной } \\
\text { продукции, тыс. тенге }\end{array}$ & 6067967 & 815085 & 3062981 & 1146 & 2183888 \\
\hline $\begin{array}{l}\text { Себестоимость ( } 1 \text { центнера, } \\
\text { тыс. штук) продукции, тенге }\end{array}$ & $\mathrm{X}$ & 4835 & 8416 & 1949 & 27078 \\
\hline Доход от реализации & & & & & \\
\hline продукции, тыс. тенге & 6943450 & 968278 & 3725410 & 1281 & 2239717 \\
\hline Цена 1 центнера реализованной & & & & & \\
\hline продукции, тенге & $\mathrm{X}$ & 5744 & 10236 & 2178 & 27770 \\
\hline Валовый доход, тыс. тенге & 875483 & 153193 & 662429 & 135 & 55829 \\
\hline $\begin{array}{l}\text { Уровень рентабельности } \\
\text { (убыточности), в \% }\end{array}$ & 14,4 & 18,8 & 21,6 & 11,8 & 2,6 \\
\hline
\end{tabular}

$$
\mathrm{X} \text { - явление отсутствует }
$$

Такого финансового результата хозяйствующие субъекты добились благодаря тому, что в последние годы развитию животноводства в области уделяется большое внимание. В рамках формирования продовольственного пояса вокруг г. Астаны в 2010 году на рынки и специализированные магазины 
столицы было поставлено: молочной продукции 55,7 тыс. тонн (рост по сравнению с 2009 годом на 121,1 тонну), яиц - 93,7 млн. штук (на 5,5 млн. штук), мясной продукции - 13,6 тыс. тонн (уменьшение по сравнению с 2009 годом на 1,2 тыс. тонны).

\section{ВЫВОДЫ И ОБСУЖДЕНИЯ}

Развитие животноводства остается одной из важных задач аграрного сектора Акмолинской области, т.к. является гарантом обеспечения внутреннего и внешнего рынков продукцией собственного производства. Реализация программы развития животноводства будет стимулировать рост перерабатывающих отраслей, рост производительности в смежных отраслях сельскохозяйственном машиностроении, пищевой промышленности, кормопроизводстве, ремонте техники. Это позволит создать новые рабочие места, предоставит источник доходов тысячам сельчан.

\section{СПИСОК ИСПОЛЬЗОВАННОЙ ЛИТЕРАТУРЫ}

1. Завгородний В.И. и др. Анализ хозяйственной деятельности сельскохозяйственных предприятий. - М.: Агропромиздат, 1987

2. Ораевская Г.И. Анализ хозяйственной деятельности сельскохозяйственных предприятий. - М.: Агропромиздат, 1985 